\title{
Pastoralism in Soqotra: external entanglements and communal mutations
}

\author{
Serge D Elie
}

\begin{abstract}
This article presents the first study of pastoralism on Soqotra Island, which is the main island of the Republic of Yemen's Soqotra Archipelago in the Indian Ocean. Its inhabitants constitute a once predominantly pastoralist community with a unique language and of mixed ethnicity who are now being enlisted in a state-sponsored and internationally-assisted conservation-with-development experiment. The article seeks to remedy Soqotrans' disenfranchisement from the academic literature on pastoralism around the world. Accordingly, it gives an overview of the nature of pastoralism on the island. This is done through the following analytical tasks: First, it provides a brief geo-cultural contextualization of the island. Second, it describes the underpinnings of a mixed subsistence pastoral regime in terms of livelihood practices, spatial mobility and residential modality. Third, it offers a provisional inventory of the pastoral flocks and herds. Fourth, and finally, the article summarizes the pastoralists' sociocultural changes resulting from Soqotra's entanglement with an externally initiated process of communal transition.
\end{abstract}

Keywords: Auxiliary livelihood; Biodiversity preservation; Middle East; Social transformation; Transhumance; Yemen

\section{Introduction: situating Soqotra}

The Soqotra Archipelago is the Republic of Yemen's ultimate frontier in the Indian Ocean, as it is situated within $250 \mathrm{~km}$ of the Somali coast on the African continent, and separated by a distance of about $380 \mathrm{~km}$ from the southeastern coast of mainland Yemen on the Arabian Peninsula. The Archipelago is composed of four islands: Soqotra, Abd al-Kuri, Samha and Darsa, in addition to a few rock formations. The Archipelago's inhabitants represent a still vibrant ethno-linguistically indigenous minority community of Southern Arabia as speakers of Soqotri, which is one of the six non-Arabic Semitic pre-literate languages of South Arabia that are collectively known as the Modern South Arabian (MSA) languages (see Elie 2012a).

Soqotra is the largest island in the Arab world (e.g. it is nearly five times the size of the state of Bahrain). Pastoralism, as a non-nomadic transhumant subsistence livelihood with herds of goats, sheep, cows and camels, remains a sociocultural pillar of the rural sector but of diminishing economic importance. Soqotrans, however, have always pursued a multiplicity of subsistence livelihoods such as fishing, date farming and geographically limited vegetable gardening. The practice of these livelihoods is contingent

Correspondence: jds_elie@yahoo.com

Yemen Center for Studies and Research, P.O. Box 7305 Sanaa, Yemen on seasons, variations in agro-ecological zones, and further constrained by the five-month summer monsoon, during which economic life comes to a relative standstill. These subsistence activities are being supplemented by increasing employment opportunities through an emerging modern economic sector (e.g. construction, tourism, salaried posts in the island's government bureaucracy as clerks, police and military personnel), and further complemented by remittances from the Soqotran émigré community in the Arabian Gulf.

Soqotra is currently being described as the 'Galapagos of the Indian Ocean' because of its endemic biodiversity, which is ranked into fourth place among the ten richest of the world's oceanic islands that are distinguished by the richness of their biodiversity. This led to the rediscovery of the island at the dawn of the twenty-first century with its designation in 1996 by the Yemeni government as a biodiversity preserve. In turn, this has engendered a dual incorporation process of the island and its people: on the one hand, the Yemeni government's modernization of its infrastructure and consolidation of its political incorporation into the national community; and, on the other hand, a United Nations-led internationalization of its economy through the implementation of an environmental protection and ecotourism development programme. This state- 
sponsored and internationally assisted dual incorporation has spawned an internal social transformation and communal transition process. The effects of the latter on pastoralism in Soqotra are the focus of this article.

\section{Study area}

Soqotra Island, which is the primary focus of this study as the main island of the Soqotra Archipelago, encompasses an area of $3,625 \mathrm{~km}^{2}$ and measures $133 \mathrm{~km}$ (82.6 miles) from west to east and $43 \mathrm{~km}$ (26.7 miles) from north to south. Its population of approximately 50,000 is divided into a few hundred clans each composed of a few extended families organized into paternal or fraternal joint households that never consolidated into tribal formations and are occupying over 600 hamlets that are dispersed throughout the island. The clans' residence in these hamlets is contingent upon seasons, weather condition and availability of resources (e.g. water and pasture).

The dominant topographical ordering of Soqotra's landscape is the natural succession of certain topographic features over most of the island's landmass that constitute five physiographic areas with varied types of vegetation: coastal arid plains (halla in Soqoți), followed by high granite mountains (fedenhen), and elevated limestone plateaus (dimidi or igalis), separated in places by internal alluvial valleys $\left(s^{\prime} i^{\prime} i b\right)$ or wadis (ephemeral seasonal river beds), and interior semi-arid plains (sheteh) that are punctuated in places with rolling hills, and finally sand dunefilled coastal plains again. This undulating topography harmonizes with, indeed dictates, the Soqotrans' practice of a seasonal altitudinal transhumance form of pastoralism that alternates with the two monsoon seasons on the island: the North East (winter) monsoon from November to March, and the South West (summer) monsoon from May to September. The island lies on the margin of the sub-equatorial and northern tropical climate belts. Accordingly, mean annual rainfall is $216 \mathrm{~mm}$ which varies across the island according to exposure and elevation: on the coastal plains, the annual precipitation may be as little as $125 \mathrm{~mm}$ or even absent altogether; while in the mountains, it can reach exceptional levels of $1,000 \mathrm{~mm}$ (De Sanctis et al. 2013: 149). In a context of high variability in rainfall and in key resource availability (e.g. water and pastures), the islanders demarcate Soqotra's landscape into zones that do not merely designate geographical locations but represent a series of natural frontiers made up of topographic signposts, climatic and altitudinal variations, agro-ecological particularities, and the types of subsistence activities they afford (see Elie 2006: chapter 3) (Figure 1).

\section{Methods}

The study that follows is based on long-term anthropological fieldwork starting in February 2002 for 18 months, and subsequently complemented by multiple visits over a ten-year period up to January 2014. My fieldwork method deployed a recursive movement between multiple locations on the island in the form of 'sites hopping', which refers to the practice of the short stay, and a pattern of commuting at irregular intervals to locations all over Soqotra in a manner that simulated the Soqotrans' opportunistic spatial displacements in pursuit of a multiplicity of livelihood-sustaining activities. This approach to fieldwork was most appropriate to the topography of life on the island, which was characterized by a population distributed into hundreds of hamlets of seasonal occupation, each with a small number of inhabitants. This context undermined the viability of the traditional one-village ethnography; instead, it obliged recourse to a research approach that privileged a cross-regional focus on the socio-spatial configuration of Soqotran pastoralists' lifeworld (see Elie 2012b). This study of a formerly predominantly pastoral polity within a sub-national territorial entity of the Yemeni state that is presently entangled in a comprehensive communal transformation process emphasizes the changing interactional dynamics between Soqotran pastoralists' ecological praxes, environmental milieu and the pastoral herds. Accordingly, it focuses on the transitional processes engendered on the island and their impacts on Soqotra's pastoralists and their way of life.

Due to space limitations, the article provides a descriptive and analytical overview of only some of the key aspects of pastoralism in Soqotra. Missing here, among other aspects, are the contemporary workings of the pastoral economy in terms of the processes of production, distribution and consumption, which will be presented in a subsequent paper (Elie 2014).

This article is organized as follows: First, it describes the specificities of Soqotran pastoralism in terms of (a) a mixed mode of subsistence driven by environmental opportunism, (b) the nature and seasonality of the spatial mobility of Soqotran pastoralists, and (c) the geography of residence in terms of the distribution of clans and villages throughout the island's sub-regions. Second, it provides a provisional inventory of the animal population. And third, it concludes with a summary analysis of the externally engendered transitional processes on the island and the resulting mutations in its pastoral way of life.

\section{Livelihood practices: pillars of a mixed subsistence strategy}

This section describes the three pivotal aspects of pastoralism in Soqotra: the environmentally and historically contingent valuation of livelihood practices, the vectors of Soqotran pastoralists' spatial mobility, and the economic geography of their pattern of residence. Soqotrans' subsistence pastoralism is practiced according to the rhythm of the two monsoons, and the seasonally programmed availability, or scarcity, of key environmental resources. 


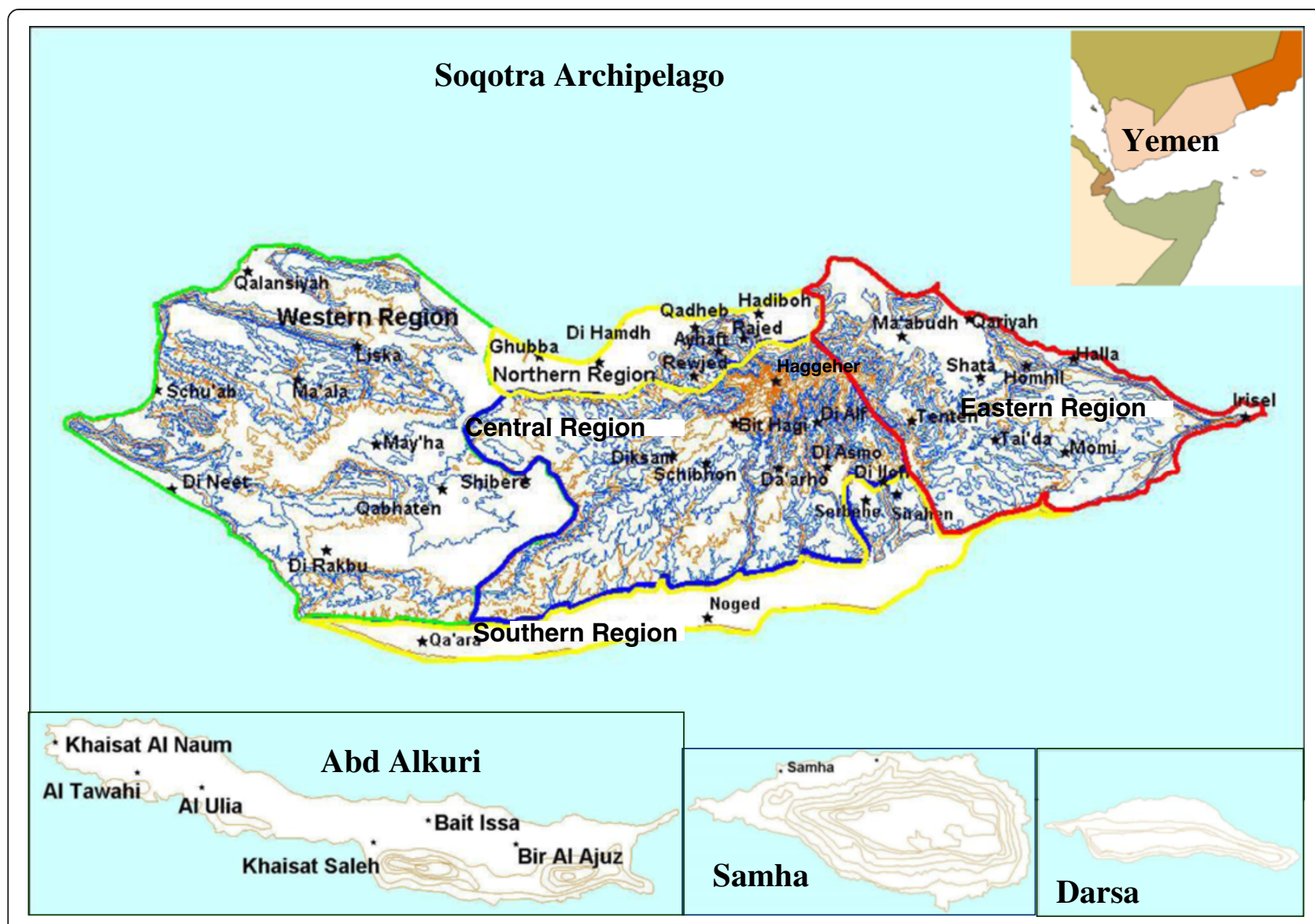

Figure 1 Map of Soqotra.

Prior to the end of the Sultanate in 1967, hunger was a seasonal fatality as the environmental dependency of the islanders was at its apogee. This dependency was relieved only intermittently, and not always reliably, by the traffic of boats carrying maqdereh (maize) from East Africa in exchange for the locally produced butter oil. Hence, every nook and cranny of the available territory was explored in search of environmental resources. Moreover, this quest for resources was not only for pastures and water - although these were critical to ensuring the survival of their animal herds - but also for wild comestible items (e.g. fruits, plants, birds, honey) to supplement the main diet made up of meat (rather infrequently), milk, dates, home-grown millet and imported maize, which was subsequently replaced by rice in the 1970s. Equally important was the search for items that could be bartered: for example, collecting fruits (such as tamarind), aloe juice, lichens from limestone mountains, resin from the bark of various trees, weaving of sheep wool rugs, gathering timber and vegetable gardening. What was significant about this quest for resources was that it occurred in a context in which survival was a permanent challenge, and where livelihood opportunities have always varied according to seasons. Hence, subsistence diversity was a prerequisite and environmental opportunism (i.e. maximizing the use of all available natural resources) the obligatory means of ensuring survival. In such a context, it becomes clear why it is erroneous to assume that 'ostensibly predominant subsistence techniques represent total subsistence strategies' (Ellen 1982: 170).

It is in this light that two recent attempts at characterizing the Soqotrans' mode of subsistence are to be evaluated. First, Naumkin (1993) insisted on dichotomizing Soqotrans into two 'economic-cultural types': the mountain-dwelling pastoralist, and the coastal fishermen. Accordingly, he argued against the designation of a third 'economic-cultural' category among Soqotrans as agropastoralist, because (a) of the minimal proportion of time allocated to land cultivation, (b) the insignificant quantity of palm trees owned, (c) the limited knowledge of other forms of agriculture, and (d) more importantly that the value of land is in its pastures not in the date palm trees. Naumkin's argument was partly motivated by a theoretical exercise that sought to reject the applicability of the dominant view that agriculture preceded pastoralism. The second attempt is by the European Union-funded team that prepared the 
Socotra Archipelago Master Plan (SAMP), which characterized Soqotrans as forming a holistic community of pastoralists. As they explained: 'For this report Socotrans are considered to form a single pastoral community... [with] an economic system in which the herding of domestic ruminant animals on open rangeland is the dominant economic activity' (Commission of the European Communities EU 2000a: 4-1). This undifferentiated characterization of the Soqotran population was motivated by the need to identify the local agent of an environment-led development policy, and the targeting of the Soqotran pastoralist for re-invention as an intuitive eco-conservationist. In both instances, the authors were aware that this pastoral economic system had undergone a mutation since the demise of the Sultanate, and thus, the dichotomous or holistic characterization amounted to an expedient reductionism: the first to validate a theory, and the second to justify a policy.

However, recourse to either discrete or amalgamating descriptive categories is not the only available analytical strategy. More appropriate is to look at Soqotran pastoralism as a mode of subsistence encompassing the aggregate of extractive processes characterizing a particular people' (Ellen 1994: 198). In other words, a mode of subsistence is constituted by an ensemble of 'subsistence techniques' that are the means with which resources are appropriated from the environment. The determinant of when a technique or a combination of them is used is what I call variable geography of livelihood opportunities, which refers to the different sets of subsistence activities afforded by the island's different geographical regions and their particular resource endowments. It is this ineluctable recourse to multiple means of subsistence that characterizes Soqotrans' livelihood making. It is a situation that cannot be analytically elucidated by specifying pure type of economic agents or generalizing about an undifferentiated pastoral community. Furthermore, the multiple livelihood practices of Soqotrans, and thus their lack of livelihood specialization, problematize the standard definition of who are pastoralists: 'populations for which livestock-related activities are the sources of more than half of total household income' (Swift and Toulmin 1992).

\section{Core vs. auxiliary livelihood: a contingently alternating subsistence repertoire}

The above situation entails the analytical challenge of articulating this environmental opportunism-inducing geographical context - that is, each region allows a different pairing of subsistence techniques and thus multiple shifts in subsistence emphasis - with the assertion that pastoralism is the dominant subsistence strategy of the Soqotran community. This articulation can be effectuated through the adoption of the distinction between core (i.e. central, foundational) and auxiliary (i.e., supplementary) subsistence activities. However, these two categories are not stable, as they alternate along three dimensions: environmental context, gendered division of household labour and historical period. In the following discussion, I illustrate how core and auxiliary subsistence activities vary along these three dimensions subject to the seasonal calendar:

First, a subsistence activity is either core or auxiliary depending on the physiographic areas (i.e. coastal plains, high mountains, high plateaux, interior valleys and interior plains), their resource endowments, climactic condition and access to alternative livelihood opportunities outside the pastoralists' primary residential domain. I schematically illustrate the alternation between subsistence activities by comparing mostly herding and fishing while neglecting a miscellany of other activities: On the coastal plains, fishing is the core activity, while date cultivation and herding are auxiliary ones. Also, for a proportion of the coastal population, especially in the north, salaried employment is the core activity with trading as an auxiliary activity, and where the cultivation of dates is an un-remunerative tradition-bound endeavour, and fishing is either an occasional leisure, or supplementary income, activity. In the high mountains, herding is the core activity with negligible participation in auxiliary activities such as date cultivation. In the high plateau areas, herding is the core activity supplemented, in the central region, by date cultivation and the collection of resin from incense-bearing trees, and in the western region, some pastoralists migrate toward the southwestern coast for seasonal fishing. In the internal valleys, herding is the core activity with date cultivation as an auxiliary one, but assumes core status seasonally. In the internal plains, herding is the core activity, which is seasonally complemented by fishing on the northern coast as the auxiliary activity. However, the subsistence activities, whether core or auxiliary, in all the island's areas are regulated by the seasonal calendar, and in particular by the occurrence of monsoon winds and seasonal rains.

Second, a gendered division of household labour further distinguishes core and auxiliary activities. In general, core subsistence activities are the responsibility of men (e.g. herding ${ }^{\mathrm{a}}$, milking, date farming and fishing), while the auxiliary ones belong to women (e.g. all household chores: water and wood collecting, cooking, milk churning, horticulture, rug weaving, pottery making). However, this gendered division concerning the performance of core vs. auxiliary chores, alternated in response to historically induced changes in the rural economy. For example, herding was principally, but not exclusively, a male activity as well as milking, but the processing of milk into different dairy by-products, but most importantly butter oil, which was the pillar of the pastoral economy, was a female activity. With the discontinuation of the export of butter oil that followed the demise of the Sultanate, and the increasing importance of fishing encouraged by the succeeding 
Socialist administration in the 1970s, herding, and even the milking of animals, at least in some places and during the extended absence of men (as milking remains taboo for women ${ }^{\mathrm{b}}$ in certain parts, as in the central mountain region in contrast to the southern coastal plains), and milk churning for the preparation of hilub (butter milk) was taken up by men, at least in some places. I witnessed one instance of this in the village of Aduno in the central internal valleys. This reallocation of task within the household was due to the seasonal migration of men to the coast for fishing and to their frequent search for odd jobs in response to the increasingly cash exigent economy. In sum, this is the extent of the division of labour in Soqotra's pastoral economy, as there is no pastoralistagriculturalist or nomad-sedentary occupational dichotomy and the corollary social antagonism that is supposed to animate the political dynamics of pastoral societies.

Third, and lastly, whether subsistence activities were core or auxiliary was a result of a historical process driven by episodes of political incorporation and their economic entailments. Three such entailments can be identified: (1) the reconfiguration of the nature of subsistence activities in terms of a gradual shift toward alternative income sources, (2) the introduction of new consumption items and a corresponding reprioritization of food resources, and (3) the reorientation of the local economy from an environmentbased and barter-mediated to a service-based and cashdriven one. The initial period of the still-in-progress historical mutation of the island's pastoral economy can be dated from the demise of the Sultanate and the beginning of the Socialist administration on the island in 1967. Soqotra can still be designated as a pastoralist community, but only if pastoralism is understood as a defining cultural leitmotif, not as the dominant economic activity. This observation does not lessen the importance of pastoralism in the Soqotrans' repertoire of socially valued activities, but seeks to distinguish between pastoralism's cultural function and its economic contribution. In terms of its cultural function, herding is valued for the social anchor - a sense of existential rootedness to the land - that it confers, rather than for its economic value. In terms of its economic contribution, herding is primarily a subsidiary food production activity (i.e. milk), since the demise of the intercontinental market for butter oil was not replaced by a market for meat. Soqotran pastoralists have become increasingly reliant on odd jobs to make ends meet, thus generating a situation in which pastoralists have moved 'from living off, to living for' their herds.

It follows from the above that the pastoral mode of subsistence in Soqotra has always encompassed multiple means of drawing resources from the environment. Furthermore, these means have varied according to agro-ecological zones, intra-household shifts in labour allocation and historically induced economic changes. These susceptibilities are intrinsic to the pastoral mode of subsistence and are generative of a chronic sense of livelihood insecurity. This raises the issue of pastoralism's sustainability as a way of life, which is further threatened by increasingly 'strong circumstantial evidence that the islands have been drying out over the last few hundred years' (Miller et al. 2003: 79) and the ensuing chronic scarcity of resource availability.

\section{Spatial mobility: seasonal peripatetics}

The nature of pastoral movements - i.e. frequency, directionality, timing, fixed or variable destination, etc. - is the key defining feature of pastoralism, hence the need to specify the type of movements of Soqotran pastoralists. The term transhumance has been used to characterize the movement pattern of Soqotran pastoralists (Naumkin 1993; Commission of the European Communities EU 2000a; Morris 2002). The use of this term is justified by the island's undulating topography and the fact that it was first used to describe seasonal herd movements that alternated between mountains and lowland pastures: 'During one part of the year the livestock is kept in mountain pastures and during the other parts is driven to lower zones'. The main purpose was to 'use other areas as seasonal pastures when they are at their optimum productivity' (Khazanov 1994: 23). Accordingly, transhumance is a spatially limited and seasonally alternating pattern of movement by (some of) the pastoralists and their herds from permanent village bases located in mountains to seasonal encampments in lowland pastures (or vice versa), due to altitudinal and seasonal variations in pasture availability. Moreover, transhumance proper can co-exist, and has done so, with other forms of pastoral movement, and thus the need to identify them accordingly. This is the approach that informs my description of Soqotran pastoralists' movements. Soqotrans seasonally reincarnate into practitioners of different livelihoods: pastoralist, fisherman, date palm tree cultivator and odd-jobber. This self-fashioning into occupational peripatetics is due to the seasonal constraints imposed on the kinds of livelihood that can be pursued at different periods of the year. These seasonal constraints provide the impetus to the different kinds of movement undertaken by Soqotrans, which I describe below.

\section{Transhumance: intra-territorial migration}

This is the principal movement among the spatial displacement patterns followed by Soqotrans, and it is the defining feature of Soqotran pastoralism. Transhumance was the foundational human practice, as a mode of livelihood, on the island. It entails a regular long-distance migration to a known destination and return to an established home base. It determines land use practices as well as settlement patterns across the island, as it entails a two-part movement across eco-topographic zones, and geographical regions, which is synchronized with the two monsoon seasons. The 
first movement is mezhìro from higher to lowland pastures and occurs toward the end of the SW monsoon season of horf in early October. The return movement is merqiyo from lower to higher grazing grounds, and it takes place toward the end of the NE monsoon season of sereb in January or after the cold weather has subsided at the higher elevation. In effect, it is a movement from a home base, an area of permanent residence to an area of temporary residence and back. The distinctive aspect of this movement is that it takes place primarily within the territorial domains of the clan collective. However, in some cases, it involves displacement to the territory of another clan in another geographical region (e.g. from central mountains to eastern plains) based on long-standing agreements. This movement is primarily for the sake of the animals. It is ultimately dependent on the seasonal variation in the weather, on whether rains have occurred, and thus on the availability of pastures and water in the places of destination, and on the condition of pastures at home base. Given the changing pattern of the weather and its impact on environmental resources, this movement's timing tends to fluctuate. Thus, it is a combination of push factors from the home base and pull factors toward the destination. The main strategies, or mobility rationales, underpinning the Soqotrans' practice of transhumance are as follows:

1. Resource conservation: this entails the search for alternative pastures, as a means of preventing overgrazing ( $m \bar{a} s ̦ e l)$, and to allow the land to lie fallow for its regeneration, which Soqotran pastoralists call kor inābut: 'so that the land can revive' (Morris 2002: 473).

2. Weather avoidance: in areas where it gets very cold, such as in the high mountains (e.g. Hajhir Mountains) and high plateau areas, pastoralists migrate to the shelter of lowland areas.

3. Follow the rain: this entails moving from dry to wet areas in search of water and pastures when rains have failed at home base.

4. Herd 're-socialization': this is especially for the goats in mountainous areas or in valleys with dense vegetation cover where they divagate unattended, and must be taken toward elevated plateau areas with sparse vegetation where they can be controlled, and thus prevented from lapsing into a feral state.

5. Livelihood alternation: pastoralists - especially those who are located in the high mountain and plateau areas and have access to date palm tree gardens in the valleys below - move to their gardens to harvest dates, while simultaneously avoiding the winds of the SW monsoon, which coincide with the harvesting period.

6. Maintenance of traditional access to land: this is specific to groups of pastoralists who transhume to land owned by others, and the use of which is based on unwritten agreements between elders of generations ago in the different communities concerned and that have sedimented over the years into an irrevocable tradition. However, these agreements are becoming burdensome for the receiving community (e.g. between pastoralist communities of the central mountains and the eastern plains); hence, movement is partly about ensuring continued access to such land.

\section{Situational nomadism: cross-territorial displacement}

The recurrent irregularity of the rain seasons, and the deleterious effects on pastures and water availability, has given rise to a displacement pattern that lacks the regularity, directionality or the altitudinal characteristics of the mezhiromerqiyo movement. This situationally constrained nomadism is a movement that is motivated by a crisis situation in which water and pastures have been exhausted by a prolong absence of rain; thus, it might be best understood as a drought management strategy. The main manifestation of this form of occasional nomadism is the mat'ino: this movement occurs not only outside the regular transhumant pattern but also more importantly outside the territorial domain of a given clan collective in search of 'drought retreats'. This movement is a form of induced nomadism as the ultimate destination is unknown because it depends on where water and pastures are found; hence, movement becomes erratic, and is no longer restricted to the regular vertical (up-down) motion, but entails a horizontal (east-west) movement pattern as well. Depending on the extent of the geographical space affected by the dry spell, the concerned clans might have to travel very far beyond their region to find adequate pastures. This movement takes place usually during the transitional seasons of gyahsh, doti or serebhen, which is a period of high livelihood stress. A scouting mission to adjoining areas to observe and inquire about the availability of water and pastures precedes the move. If these two resources are found in sufficient quantity, then a formal request is made to the responsible persons (muqad$d a m$ ) of the receiving village or area. This request (yish'hallin) for permission to move into the territory of the clan is made for a specific period of time - usually until it has rained in the villagers' land - to graze animals and set up household. This request might involve an individual family or a whole group. Once permission is granted, the next step is $t a^{\prime} a n$, which involves moving the herd and setting up household under strict arrangements regarding what land space to be used and the house to be occupied by the family. Depending on prior agreement with the landowners, a compensation fee (mizbido or gizire of kire according to region) usually in kind could be paid to them. This movement represents another form of mutual aid practices, as part of culturally elaborated conventions for intra-communal socio-environmental relations. 


\section{Agropastoral movement: food harvesting relocation}

This movement not only illustrates the notion of seasonal peripatetics, as it involves the mutation of coastal fishermen and hinterland pastoralists into date farmers, but also the seasonal as well as historical alternation between core and auxiliary subsistence activity. Agropastoral movement concerns essentially date harvesting in the regions where there are date gardens. In historical terms, date harvesting was the high point in the cycle of livelihood making, as it brought relief to the seasonal hunger that befell Soqotrans just prior to, and during, the horf season, as dates were considered the most effective hunger suppression food. The date garden was a wealth and social status marker and was the main form of investment from the Soqotran diaspora in the Arabian Gulf until the early 1990s. The movement to date gardens is called yaharuf from the verb haruf meaning 'to harvest dates'. This movement took place just prior to the beginning of the SW monsoon season of horf from the fishermen or the pastoralists' permanent residence to the date gardens during the harvesting period, which is during the months of June and July. In some places, as in the central region (e.g. Hajhir Dit Fahed), the people use a relay system, as they go to the date gardens for a few days and return to their village for a period of rest. In other places, such as Hadiboh, date farmers move to their date gardens for the duration of the harvest, at which time Hadiboh is partially emptied of its residents. This movement is still practiced by many people, although it is less extensive than during the Sultanate period, when it constituted a major seasonal event on the island (see Elie 2004: 73). This movement is partly linked to the end of the school year and the beginning of a three-month vacation period, and entails the seasonal desertion of some settlements on the northern coast either toward date gardens, or more generally for hinterland settlements in order to escape the winds.

Finally, movement in all of its forms remains an intrinsically weak link in the pastoral mode of livelihood, as it could undermine commitment to it. As Blench (2000) explains, 'Pastoralists exist along a gradient of willingness and capacity to move'. It is this 'willingness', which can be gradually compromised by the availability of alternative means of livelihood that are less demanding than pastoralism and less susceptible to seasonal limitations or uncertainties. This threshold, however, has yet to be crossed, at least not permanently - it is straddled instead - as no livelihood alternative has yet to escape the ineluctable seasonal constraints on all economic activities on the island. The only exception, thus far, is the limited number of salaried jobs available through government posts and as staff member of the few projects of the UN and international NGOs. Indeed, it is the exigencies of the seasonal calendar that determine the movements associated with all livelihood activities on the island. Accordingly, the seasonal calendar presented in Table 1 seeks to articulate the interaction between seasons, climactic conditions and their socio-economic ramifications for life on Soqotra.

\section{Geography of residence: regions, villages and clans}

Soqotrans' occupation of the island's landscape is characterized by the wide dispersal of settlements. It is as if an 'atomization imperative' was driving them to spread themselves in a myriad of micro-encampments throughout the landscape. This widely dispersed residential pattern, which was partly driven by the unpredictable seasonal availability, and alternating topographic location, of key environmental resources, and further mediated by contingent historical forces, has determined the shifting geographic location of livelihood opportunities. Table 2 attempts to present the current, but still evolving, configuration of the residential geography of Soqotrans. In the table, the island is divided into five regions, which are the actual geopolitical zones established for political management purposes - i.e. demarcation of traditional local representative (shaykh) jurisdiction - and encompassing 43 areas. However, the table lists 45 areas; this is due to the inclusion of Hadiboh suburb and Sheteh Qalansiyah (lowlands of Qalansiyah), which are not political jurisdictions but geographical demarcations. These areas are in fact informal sub-districts demarcating the political domain of the 43 locally selected and government approved shaykhs as well as the self-appointed ones. They are informal since they are not recognized in the Local Authority Law enacted in 2000 and are subsidiary to the formally established 36 sub-districts constituting the Eastern (Hadiboh) and Western (Qalansiyah) Districts of the island, and for which Local Councilors are elected (see Elie 2009 for details). The order, in which the areas are presented in the table, is from the perspective of traveling from Hadiboh town, the island's political centre, toward each region. The topographic designations of each area reflect the landscape zoning already discussed above. Each area refers to an agglomeration of villages spread over a given territory and is named after, but not in all instances, the main village in which a mosque (esp. for Friday prayers), a clinic and a school are located, and for which a shaykh is either officially designated or self-appointed. Finally, each area is further sub-divided into individual villages and hamlets shared by clan collectives and headed by a clan or village leader the muqaddam.

The figures for villages and clans are based on a number of sources: the author's systematic, but not exhaustive, collection of information directly in the regions; from knowledgeable individuals from the regions; and a systematic review of the data from the 2004 census. It is on the basis of the latter that the population distribution of the island was arrived at. The social information is based on my personal observations, complemented by multiple informants. Also, the number of villages identified (869) includes 


\section{Season Period}

Qeyat Transitional post-winter monsoon

(3-4) season: from March to April.

Occurs in the spring, but considered

as Soqotran 'summer'.

Gyahsh Spring transitional period between the Expected to bring pre-summer rains to

(4-5) two monsoons: from mid-April to mid-May.

Overlaps the end of spring and

beginning of summer, and buffers

the dry doti season.

Doti (4-6) Transitional pre-summer monsoon season: from late April to early June.

\section{Climate}

Rains are sporadic and spotty, but mostly

rare. Water and grazing availability is limited.

Weather is warm to pleasant. Westerly

winds affect the southern part of

the island.

some parts of the pre-sum

Relatively hot, as SW winds die down

and before SE winds start.

Unpredictable summer rains, mostly in highland areas, are seen as harbinger of whether or not drought will follow.

Straddles late spring and early summer.

Weather is generally cool and breezy if it rains.

Grazing grounds in wet areas are covered with grasses. Water availability is variable.

Gale force medeh winds averaging $70 \mathrm{mph}$ Strongest impact on northern Coastal Plains (CP), and High Mountains (HM), and mildest longest on the island Lasts n five mon on Internal Valleys (IV), and Internal Plains (IP).

Straddles end of summer and mid-fall. Hottest period of the year and very dry. Absence of rains, thus scarcity of grazing and water.

Depleting rain water catchments (karifs esp. in west and east) are replenished with purchased water trucked in from Hadiboh wells.

\section{Socio-economic activities}

Pollination of date-palm trees wherever they

are cultivated.

Celebration of Muslim holiday id al-ädhhāa, the

main occasion for the sale of large numbers

of livestock, esp. sheep, male goats (mi'shur)

and ram (kubs) for obligatory sacrificial ritual.

Its seasonal occurrence varies as it depends

on the lunar calendar.

Out of season semi-nomadic movement in search of appropriate pastures either in or out of territorial domains.

End of tourism season

Import of animal feed - barley (sha'ir), flour (qahm) and wheat shaft (sabus) - in expectation of absence of rains in the horf season.

Livestock come into season, and sheep and goats are mated to give birth in sereb. Prior to this period, breeding would normally be discouraged in order to avoid birth during water and grazing scarce horf season.

Out of season semi-nomadic movement from dry to wet areas to feed animals prior

Preferred marriage season, as sufficient cash was accumulated during the previous sereb season.

Extensive out-migration of fishermen from coastal villages around the island and of pastoralists from the hinterland to villages in Hadhramawt and Mahra for one to three months to work as fishermen, herders, or construction labourers.

Economically moribund time of year, as sea is closed to fishing and shipping. Some fishermen from the northern and southern coasts migrate to the mainland to work as fishermen, among other temporary occupations.

Closure of school for summer vacation (June-August) and partial migration of residents from northern coast toward hinterland settlements and to date gardens.

Season for date harvesting, drying and storing for later consumption (esp. during Ramadhan). Also, harvesting of aloe juice (esp. in the west) 
Serebhen Autumn transitional period that

From late September and mid-October: transitional months between summer and winter.
Water levels at their lowest, and rangelands are bare, esp. in $\mathrm{CP}$, IP and HP areas.
NE winter monsoon season: from late October to early February.

Straddles the fall and winter.
Main season for honey production by

hundreds of bee-keepers in villages around

the island, which has partially replaced

wild honey harvesting.

Departure of mainland workers and stoppage

of all construction works and road building.

Washing and shearing of sheep wool for

weaving rugs, especially in the east where rug

production is integral to household activity.

Onset of mezhi period when medeh winds die down and signals the beginning of the main transhumance movement mezhiro: from higher to lower grounds.

This period serves as catalyst of the mezhiro transhumant movement, which is usually within the territorial domain of the clan collectives. The severity of water scarcity might necessitate resorting to alternative coping strategies:

(a) Activation of mutual aid system, as most affected pastoralists canvass other territories seeking permission from owners to graze their livestock.

(b) Purchasing of cereals such as barley, wheat shaft and flour to feed the herds.

(c) Selective cutting of particular trees, based on local knowledge repertoire, to use as fodder in the absence of grass.

Reopening of schools (Sept-May) and return migration from the hinterland to Hadiboh town especially, but to all coastal settlements.

Reactivation of economic life, as sea opens for shipping and fishing.

Ecotourism season begins.

Parturition season (esp. for goats and sheep) and animals are lactating. Main period for pastoralists to sell two-week-old male kids in Hadiboh.

Main season for milk production and

consumption, which reduces dependence on some purchased food items. Also, production of butter oil from cow and goat milk for sale in 1-litre plastic bottles.

Breeding season for cattle in central and eastern regions. to December.

High water availability in most regions and the replenishment of rain water catchments (karifs and lims). 
Table 1 Soqotra's seasonal calendar (Continued)

Milder serbihi winds, cold in higher

elevation and cool/pleasant in

lowland areas.
Home gardening activities (planting and caring)

start early in the season.

Greater availability for odd-jobbing opportunities

(e.g. construction, tourist guides).

Preferred visiting period of Sogotran émigrés

from the Gulf.

Migration from the hinterland to the coast for fishing

Second honey collecting season depending on rains.

Buying and storing of food (esp. sacks of rice and flour), as form of food security, to last through the next horf season, when there is usually a shortage in local supply or a substantial price hike.

Ramadhan, whatever the season of its occurrence, is a period of custom-obligated meat consumption The occurrence varies depending on the lunar calendar. This is followed by id al-ädhhä, which is a major occasion for the local sale of livestock

Return of mainland migrant workers.

Onset of zuhum period, the end of sereb, when kids and lambs are weaned. And beginning of merogihi, and the return transhumance

movement, meraìyo: from lower to higher grounds. This takes place toward the end of January, or later.

Harvesting of vegetables and fruits from home gardens around the island, which are primarily for sale (and not for home consumption) in

Hadiboh until the end of February.

Note: The table is based on fieldwork observations and complemented by personal communication with Dr. Morris, and from Morris (2002), and Miller and Morris (2004) especially for the Soqotri terms, the timing of the seasons and some of the related socio-economic activities. Under the 'Season' column, numbers are provided in parenthesis, which refer to the months of the year, as Soqotrans use Arabic numbers to designate months - e.g. month one (shahr wahed). Under the 'Period' column, the seasons of spring, summer, fall and winter are referred to as a means of identifying the seasonal equivalence with the solstice calendar. 
Table 2 Geography of residence in Soqotra

\begin{tabular}{|c|c|c|c|c|c|}
\hline Regions & Areas & Topography & Villages & Clans & Particularities \\
\hline \multirow{7}{*}{$\begin{array}{l}\text { Northern } 32 \% \\
(14,000)\end{array}$} & Hadiboh & Coast & Town & NA & \multirow{7}{*}{$\begin{array}{l}\text { Heterogeneous clan as well as ethnic composition with approximately } 83 \text { clans sharing } 103 \text { villages, thus giving it a centripetal } \\
\text { settlement pattern. Its share of } 32 \% \text { of the population represents the highest concentration of relatively sedentary inhabitants on the } \\
\text { island. They are engaged in diversified occupations (govt. staff, fishermen, agropastoralists, petty traders, etc.). There is herding activity } \\
\text { of goats mostly. There is higher access to public amenities, due to its location as the island's political and economic center, main } \\
\text { seaport and airport. }\end{array}$} \\
\hline & $\begin{array}{l}\text { Hadiboh } \\
\text { (suburb) }\end{array}$ & $\mathrm{CP}$ & 38 & NA & \\
\hline & Qadheb & $\mathrm{CP}$ & 5 & 12 & \\
\hline & Ayhaft & $\mathrm{HM}$ & 8 & 5 & \\
\hline & Rewjed & $\mathrm{HM}$ & $23^{*}$ & 6 & \\
\hline & Di Hamdh & $\mathrm{CP}$ & 12 & 43 & \\
\hline & Ghubba & $\mathrm{CP}$ & 17 & 17 & \\
\hline \multirow{9}{*}{$\begin{array}{l}\text { Central } 7 \% \\
(3,000)\end{array}$} & Diksam & $\mathrm{HP}$ & $111^{*}$ & 9 & \multirow{9}{*}{$\begin{array}{l}\text { Highly homogeneous clan composition with highest number of villages (358) per individual clans (67), thus strong centrifugal } \\
\text { settlement pattern, which reflects the practice of an extensive pastoralism, and on which the inhabitants are highly dependent. Date } \\
\text { cultivation is restricted to the IV areas. Has lowest level of population (7\%) with a relatively specialized livelihood, as semi-nomadic } \\
\text { pastoralists possessing a diverse herd composition, in which cows are the dominant animal. Has the least access to public amenities. }\end{array}$} \\
\hline & Shibhon & $\mathrm{HP}$ & $30^{*}$ & 3 & \\
\hline & Da'arho & IV & 12 & 1 & \\
\hline & Difshe & IV & 11 & 3 & \\
\hline & Di Asmo & IV & 10 & 2 & \\
\hline & Klim & $\mathrm{HP}$ & 9 & 5 & \\
\hline & $\begin{array}{l}\text { Hajhir (3 } \\
\text { parts) }\end{array}$ & $\mathrm{HM}$ & $122^{*}$ & 19 & \\
\hline & $\begin{array}{l}\text { Sha'ab Di } \\
\text { Alf }\end{array}$ & IV & 23 & 17 & \\
\hline & $\begin{array}{l}\text { Sha'ab Di } \\
\text { llofi }\end{array}$ & IV & 18 & 8 & \\
\hline \multirow[t]{5}{*}{$\begin{array}{l}\text { Southern } 10 \% \\
(4,600)\end{array}$} & $\begin{array}{l}\text { Iglisu } \\
\text { Serbehe }\end{array}$ & $\mathrm{HP}$ & 9 & 5 & \multirow{5}{*}{$\begin{array}{l}\text { Moderately heterogeneous social composition with relatively proportionate distribution of clans (36) to villages (53), thus a centripetal } \\
\text { settlement organization facilitated by the collective nature of primary livelihood activity, fishing (esp. lobster). This is complemented by } \\
\text { agropastoral activities (i.e. date and vegetable cultivation, and herding). Ranks fourth in population proportion (10\%) with inhabitants of } \\
\text { variable mobility, and inadequate access to public amenities. }\end{array}$} \\
\hline & Sirahen & $\mathrm{HP}$ & 10 & 7 & \\
\hline & Mahfirhen & $\mathrm{CP}$ & 1 & 6 & \\
\hline & Noged & $\mathrm{CP}$ & 11 & 7 & \\
\hline & Qa'ara & $\mathrm{CP}$ & 22 & 11 & \\
\hline \multirow{7}{*}{$\begin{array}{l}\text { Eastern } 19 \% \\
(8,400)\end{array}$} & Ma'abudh & IV & 12 & 21 & \multirow{7}{*}{$\begin{array}{l}\text { Relatively heterogeneous clan composition with greater number of clans (137) than villages (124), thus having a centripetal settlement } \\
\text { pattern. Region straddles multiple topographical terrains, thus population has access to diverse livelihood sources (e.g. fishing, date and } \\
\text { vegetable gardening, and herding). This is complemented by (in-kind) remittances from relatives in the Gulf and local government jobs } \\
\text { in Hadiboh. Ranks third in population proportion (19\%) with moderate availability of public amenities. }\end{array}$} \\
\hline & Dibna & $\mathrm{CP}$ & 4 & 1 & \\
\hline & Tentehen & $\mathbb{P}$ & 16 & 19 & \\
\hline & $\begin{array}{l}\text { Tiyda' } \\
\text { (Shizeb) }\end{array}$ & $\mathbb{P}$ & 18 & 10 & \\
\hline & Sheteh & $\mathbb{I P}$ & 21 & 25 & \\
\hline & Momi & $\mathrm{HP}$ & $74^{*}$ & 24 & \\
\hline & Homhil & $\mathrm{HP}$ & 14 & 5 & \\
\hline
\end{tabular}


Table 2 Geography of residence in Soqotra (Continued)

\begin{tabular}{|c|c|c|c|c|c|}
\hline & Qariyah & $\mathrm{CP}$ & 4 & 13 & \\
\hline & Halla & $\mathrm{CP}$ & 11 & 13 & \\
\hline & Irisel & $\mathrm{CP}$ & 10 & 6 & \\
\hline \multirow{14}{*}{$\begin{array}{l}\text { Western 32\% } \\
(14,000)\end{array}$} & Qabhitin & $\mathbb{I P}$ & 32 & 14 & \multirow{14}{*}{$\begin{array}{l}\text { Homogeneous clan composition with relatively unbalanced distribution of clans (86) to villages (189), thus a centrifugal settlement } \\
\text { pattern. Population is primarily engaged in goat herding and some sheep, as there are no camels, cows or donkeys; highly mobile } \\
\text { pastoralists due to high water scarcity given the dominant topography of arid internal plains; minimal to non-existent access to public } \\
\text { amenities. Ranks second in population proportion (32\%). However, this figure is based on the geographical division of the island, and } \\
\text { not on its political division which allocates a sizable portion of the west to the Eastern District (e.g. Qabhitin). Some pastoralists } \\
\text { undertake seasonal fishing on the northern and southern coasts. Indeed, the fishing settlements of the western end of the southern } \\
\text { plain are made up of people from this region. With the exception of Qalansiyah town and Qeso village, the region is bereft of } \\
\text { vegetable gardens and date cultivation. }\end{array}$} \\
\hline & Kishin & $\mathbb{I P}$ & 10 & 7 & \\
\hline & Di Rakbu & $\mathbb{I P}$ & 15 & 6 & \\
\hline & Shibere & $\mathbb{I P}$ & 10 & 4 & \\
\hline & Mayha & $\mathbb{I P}$ & $47^{*}$ & 16 & \\
\hline & Ma'ala & $\mathrm{HP}$ & $49^{*}$ & 9 & \\
\hline & Shu'ab & $\mathrm{CP}$ & 3 & 7 & \\
\hline & Di Neet & $\mathrm{CP}$ & 6 & 5 & \\
\hline & Stum & $\mathbb{P}$ & 4 & 7 & \\
\hline & Liska & $\mathbb{P}$ & 2 & 1 & \\
\hline & $\begin{array}{l}\text { Sheteh } \\
\text { Qalansiyah }\end{array}$ & $\mathbb{P}$ & 11 & 10 & \\
\hline & Qalansiyah & Coast & Town & NA & \\
\hline & Samha & Island & NA & NA & \\
\hline & Abd al-Kuri & Island & 6 & NA & \\
\hline Total & 45 & & 869 & 409 & \\
\hline
\end{tabular}

$\mathrm{CP}$, coastal plains; $\mathrm{HM}$, high mountains; $\mathrm{HP}$, high plateau; IV, interior valleys; IP, interior plains. 
hamlets as well as seasonally uninhabited grazing areas used for transhumance, and are just as important to pastoralists as are inhabited villages. The actual number of settlements might be slightly higher than 900 , and the number of clans might be nearer 500. In contrast, the census in 1994 was based on 880 villages, and that in 2004 covered 629 villages. The inclusion of uninhabited grazing areas is most evident in the central and western regions and is identified with an asterisk (") under the 'Villages' column. The number of clan collectives (409) does not always include clan sub-divisions, which seems widespread (e.g. in the internal plains of the western region). Also, the term 'tribes' is not used in the table, although that would be in keeping with Soqotrans' self-reference as belonging to tribes. However, it is more accurate to characterize them as clan collectives. This is because a clan constitutes a limited group of households united by a common interest in survival, and occupying a collectively owned territory inherited from their putative common ancestors, and whose criterion of membership is not common descent but common geographical origin, or the clan territory called dabar in Soqoți. Even the
Soqotran's definition of clan captures the symbiotic nexus between social organization and environmental context: the term shațr (meaning: part, section, segment), which is borrowed from Arabic and is attached to a Soqoți suffix, gives the following word: shatrihir, which means strips from a cloth. In effect, it describes the amoeba-like sub-division process of Soqotra's clan formation as well as evokes the image of a cloth being torn apart continuously into everthinner strips, partly to accommodate the spatial requirements of grazing herds as part of an extensive form of pastoralism. Indeed, the socio-political organization of the Soqotran community into atomized clans instead of aggregated tribes was structured through the symbiosis between the island's physical geography and the constitution of its social geography: that is, the natural human habitats made available by the island's physical geography have engendered the dispersed nature of its social geography (Figure 2).

Regarding the rural-urban population distribution, it is noteworthy that the only two towns on the island have nearly a third $(12,407)$ of the total population of 44,120 : Hadiboh (8,545 partly inflated by mainlanders) and

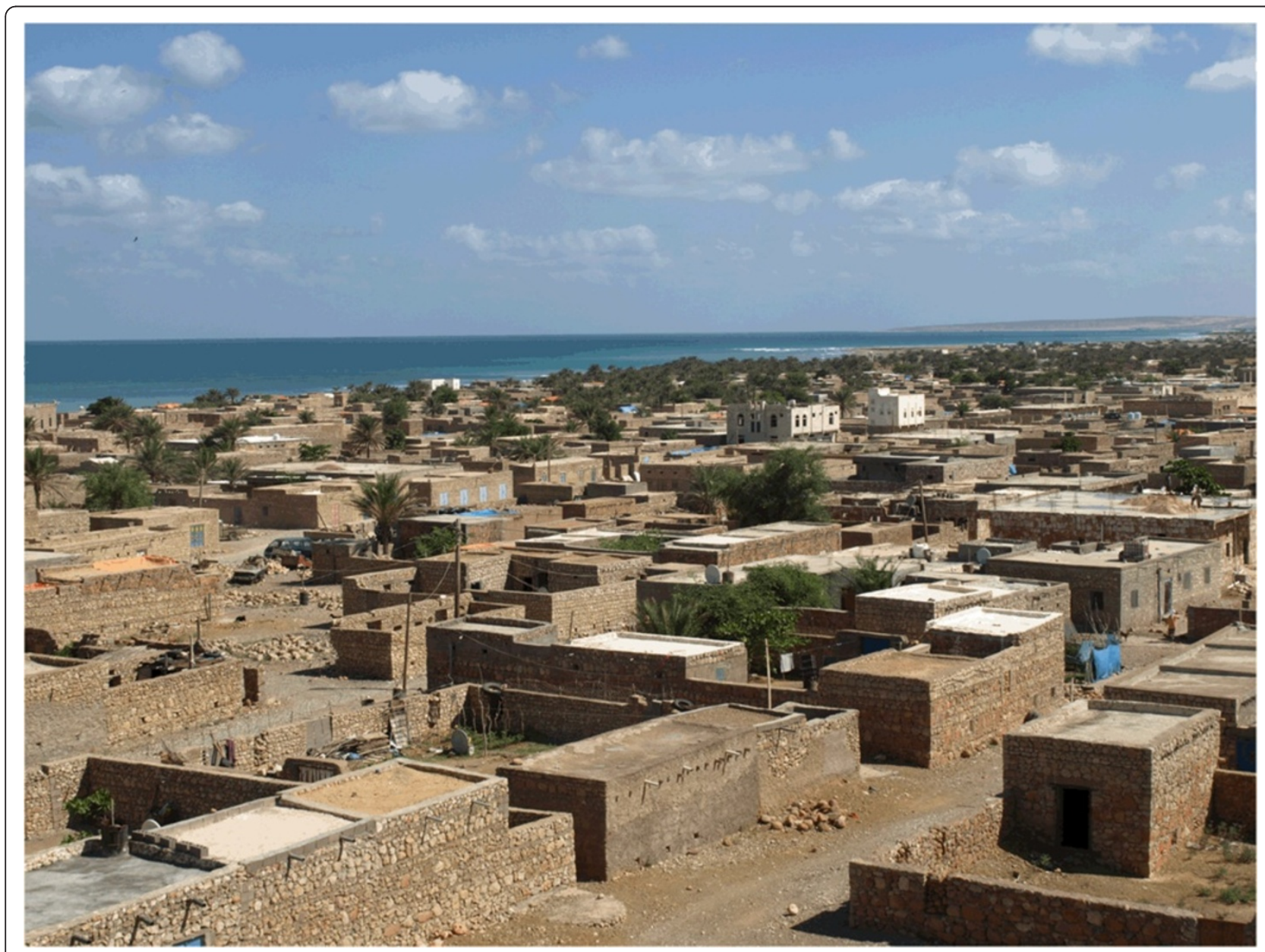

Figure 2 Partial view of Hadiboh town. 
Qalansiyah $(3,862)$. The fact that these two towns are located on the northern coast not only confirms that the coastal areas have well over half of the total population but also indicates an inexorable urbanizing, or 'coastalizing', trend. Moreover, by excluding the population of these two towns, and dividing the remaining total $(31,713)$ with the number of villages (629) included in the census, the average population per village (50.4) corroborates my characterization of Soqotra as a clan-based 'atomistic community' in which the island's landscape is sundered into an archipelago of clans' hamlets. In fact, only about $10 \%$ of the non-urban population lives in villages of more than 100 inhabitants. The average population in the overwhelming majority of villages is in double-digit figures, which is partly an effect of the land-extensive herd management system (Figure 3).

Finally, the particularities identified for each region are an attempt to provide a succinct, yet tentative, analytical summary in guise of a sociological profile, which expresses the nature of the relationship between residents in different regions and their environment or geographical milieu, as mediated by livelihood practices, which influence population movement, settlement pattern and landscape use. This profile is articulated around the use of two concepts: First, homogeneity, which refers to a population composition that is made up exclusively of related clans engaged in herding activities. This kind of activity is accompanied by a settlement pattern that is centrifugal in orientation because of the extensive (as opposed to intensive) nature of pastoralism in Soqotra. Second, heterogeneity refers to a resident population composed of unrelated clans engaged mostly, but not exclusively, in trade-related activities (e.g. fishing) and are organized in a settlement pattern that is centripetal in orientation because the nature of the economic activities attracts a greater population concentration from diverse locations and clans. These terms are operationalized according to the following criteria: (a) the determination of the homogeneity or heterogeneity of a region's clan composition is based on the ratio of villages to clans: the higher the number of villages vis-à-vis the number of clans, the more homogeneous the social composition, or vice versa, (b) whether the pattern of settlements in a region tends

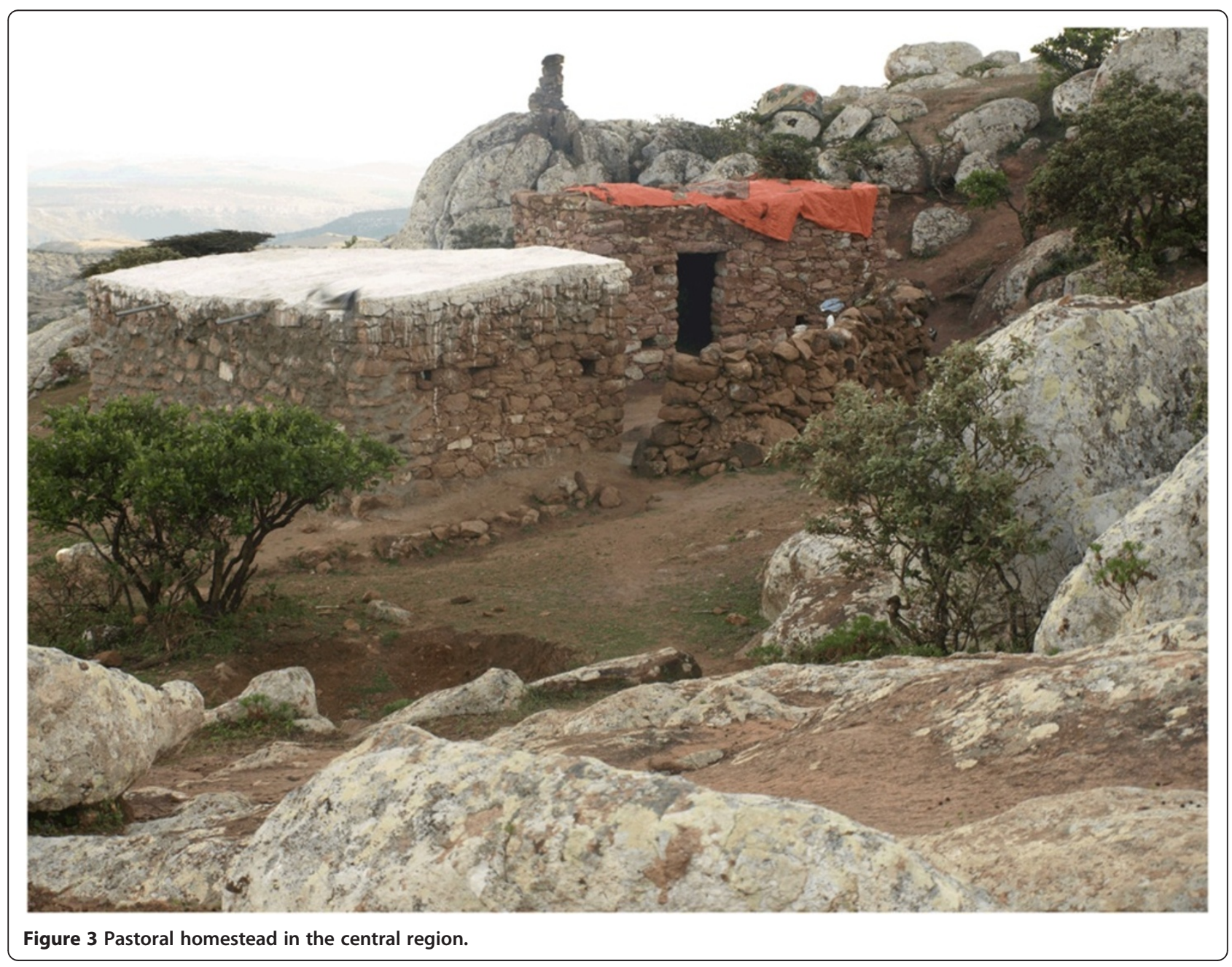


toward agglomeration (centripetal) or dispersal (centrifugal), which is determined on the basis of the same criteria for assessing homogeneity and heterogeneity, (c) ranking in population distribution, (d) nature of livelihood activities, and (e) the availability of public amenities: schools, clinics, mosques and government offices. What is clear is that the coastal areas and especially the two urban centres are the migratory poles in an established and accelerating trend of internal migration on the island.

\section{The pastoral fauna: a provisional inventory}

Missing, thus far, from the above discussion is Soqotra's pastoral herds, which is the foundation of the pastoral mode of livelihood that I have been discussing. After more than a decade of international interventions on the island, there are no reliable data on the composition and distribution of livestock around the island. The continuing absence of a reliable census of Soqotra's pastoral herds is a testament to the myopia of both the mainland government and the plethora of international aid agencies, whose focus for more than ten years of intervention and tens of millions of dollars spent on projects was, and remains, almost exclusively on the preservation of endemic species. In fact, the most basic set of information about Soqotra's pastoral system is missing: a) the population and distribution of the livestock herds around the island, b) the extent to which the once effective pastoral management system is still in use or has become dysfunctional, and c) the nature of the ecological effects of the above. For over a generation, the information regarding the livestock population has been based on back-of-the-envelope estimations, as is presented in Table 3 below.

These varying figures betray the unreliability of these censuses; nevertheless, they offer a comparative glimpse, even if largely imagined, on the historical trajectory of Soqotra's pastoral herd. While lack of a serious effort on the part of external actors is to be blamed, to be fair, however, this data deficit is exacerbated by the chronic reluctance of Soqotran pastoralists to share the actual numbers of their herds. There are many reasons given for this reluctance: (a) pastoralists really do not know the actual numbers of their herds given their lack of numeracy, (b) the legacy of secrecy about one's assets (whether human or animals) inherited from the Socialist era when the government 'abducted' sons from pastoralist families to be educated in boarding schools away from their villages and parents and (c) hasad wa 'ain ('envy and evil eye'), which one pastoralist described in rather hyperbolic term as the 'the Bedouins' creed' (al-'aqida al badī) to refer to a primal fear among pastoralists about talking about their herd size due to the ominous consequences on the fate of their animals. However, the justification for this reluctance that seems to capture the essence of the problem was explained in more modern metaphorical terms by an urbanized former pastoralist as follows: 'It is like asking people how much money they have in the bank'. This is a question that most people would be reluctant to answer. Nevertheless, that reflexive reluctance about revealing herd size could be disarmed in exchange for needed assistance (e.g. veterinary services).

Today, the actual figure for the population of livestock in Soqotra remains elusive, and the most recent attempt to remedy this situation is still unsatisfactory. Nevertheless, the figures obtained from the 2002 unpublished agricultural census are presented in Table 4 for illustrative purpose only. They are cited in the official development plans of the two districts of Soqotra: An Overview of Development for the District of Hadiboh (2006:20) and The Development Report for the District of Qalansiyah (2007:37). Finally, my use of these figures is due first to the fact that is all there is, and second to their seeming plausibility given that most numbers are not rounded off, which suggests an attempt at actual counting not just estimating, even though the difference with the figures in Table 3 suggests either they are far-fetched or that the previous censuses were partial sampling of the pastoral herds.

On the basis of these figures, a few observations can be made: First is the regional variation in herd composition,

Table 3 Historical data on Soqotra's pastoral herds

\begin{tabular}{|c|c|c|c|c|c|c|}
\hline \multirow[t]{2}{*}{ Census dates } & \multicolumn{5}{|c|}{ Animals } & \multirow[t]{2}{*}{ Notes and sources } \\
\hline & Goats & Sheep & Cattle & Camels & Donkeys & \\
\hline 1966 & 19,000 & 26,000 & 1,800 & 350 & 500 & $\begin{array}{l}\text { It may have been the first, albeit informal, census, which was carried out by the British } \\
\text { colonial officer Brown (1966), who candidly confessed that 'field counts are at best only } \\
\text { better than guess work'. }\end{array}$ \\
\hline Mid-1980s & 71,000 & 17,500 & 1,900 & 500 & NA & $\begin{array}{l}\text { Cited in (Commission of the European Communities EU 2000b) Sectoral Report: } \\
\text { Agriculture and Livestock (pp. 2-5) without identifying source. }\end{array}$ \\
\hline Mid-1990s & 90,000 & 60,000 & 12,000 & 5,000 & 2,000 & $\begin{array}{l}\text { These figures are supposed to be from the } 1994 \text { agricultural census by the government of } \\
\text { Yemen. Given to the author by a staff from Soqotra's branch of the Ministry of Agriculture. }\end{array}$ \\
\hline 2000 & 29,300 & 7,300 & 2,500 & 400 & NA & $\begin{array}{l}\text { Conducted by the European Union Agriculture \& Livestock team in } 2000 \text { as part of } \\
\text { the preparation of the Sogotra Archipelago Master Plan. It took place soon after a major } \\
\text { drought, which killed an estimated } 60 \% \text { of the livestock. }\end{array}$ \\
\hline
\end{tabular}


Table 4 Census of Soqotra's pastoral herds (2002)

\begin{tabular}{lllllll}
\hline Districts & \multicolumn{2}{l}{ Animals } & & & & Grand total \\
\cline { 2 - 6 } & Goats & Sheep & Cattle & Camels & Donkeys & \\
\hline Eastern (Hadiboh) & 178,000 & $26,280^{c}$ & 10,629 & 66 & 968 & 215,943 \\
Western (Qalansiyah) & 274,840 & 75,246 & 0 & 0 & 0 & 350,086 \\
Total & 452,840 & 101,526 & 10,629 & 66 & 968 & 566,029 \\
\hline
\end{tabular}

and the surprisingly higher number of goats and sheep in Qalansiyah than in Hadiboh district, in spite of the latter's larger territorial expanse and higher human population. However, this is compensated by Hadiboh's more varied herd composition. These figures, whatever their degree of reliability, confirm the cultural distinction between the east and west (i.e. that cattles are neither herded nor eaten in the west), and more importantly, the enforced herd specialization in the west is due to its greater aridity than the east. Also, the larger number of herds in the west suggests a deliberate strategy of claiming territorial grazing rights, if not land ownership, through the presence of specific clan-related herds on the land, in order to make up for the absence of human residents given the west's relatively sparse population. This confirms the fact that pastoralism in Soqotra is first and foremost a mode of territorial occupancy in which the value of the herds is primarily as markers of individual pastoral families as shared 'owners' in the clan collective's territorial commons; and only secondarily a system of livestock production. Furthermore, it might also suggest the deployment of a risk management strategy through the 'maximum-standing-stock' technique of herding where there is a maximization of herd size as an adaptation strategy to the west's chronic deficit of environmental resources. This risk management strategy seeks to ensure the survival of part of the herds in case of resource failure, and not what appears through casual observation as the abandonment of herd management. Second, the livestock population density for the island as a whole is 156 animals per $\mathrm{km}^{2}$, which is much higher than the human population density of 12.17 persons per $\mathrm{km}^{2}$. Disaggregated at the level of district, the animal density for each district is as follows: for the Eastern district, which occupies less than a third of the island (approx. $995 \mathrm{~km}^{2}$ ), the herd density is 351.9 animals per $\mathrm{km}^{2}$, and for the Western district, which occupies more than two thirds of the island (approx. 2,630 $\mathrm{km}^{2}$ ), the herd density is 82.1 animals per $\mathrm{km}^{2}$ (Figure 4). ${ }^{\mathrm{d}}$

Relatedly, the average size of the herd per family/ household (with an average of 7.59 persons) in the

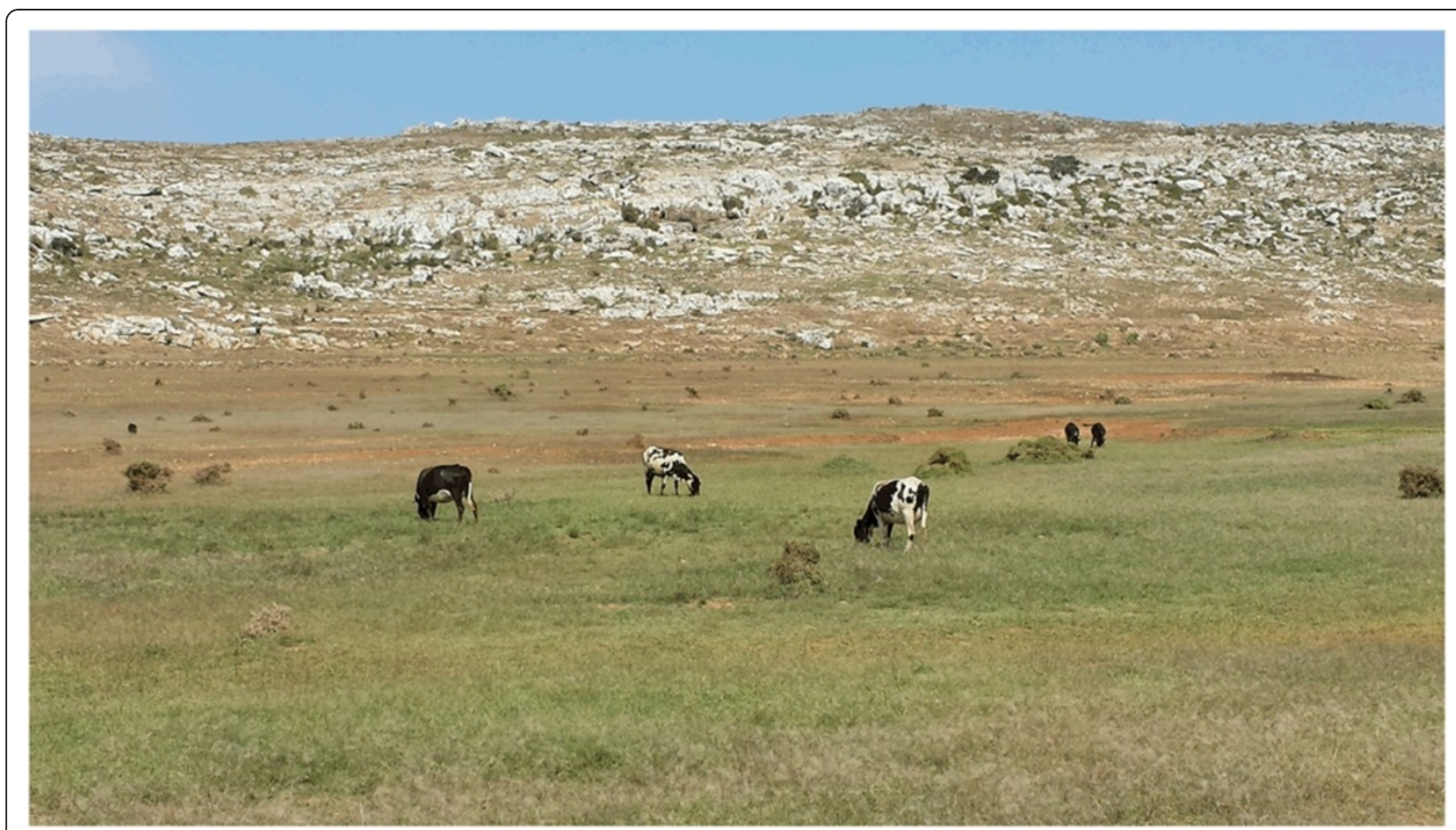

Figure 4 Cow pastures in the eastern region. 
pastoral areas excluding the urban areas is 295.50. The optimal size of herds has not been determined in the context of Soqotra's grazing resources and the frequency of the island's climatic vagaries (e.g. unpredictable rainfall and drought); therefore, it cannot be ascertained whether this figure exceeds the island's carrying capacity - if such a measure can be meaningfully established. This figure is based on taking the total number of families outside the two towns of the island as listed in the census report in 2004 (Central Statistical Organization CSO 2004: 137, 141) and dividing them by the total herd figure. Using the same formula, but disaggregated by district, the breakdown of the average number of animals per rural household is as follows: for Hadiboh district, it is 60.56 animals per each of the 3,516 rural families out of a total of 4,658 families, and for Qalansiyah district, it is 530.43 animals per each of the 660 rural families out of a total of 1,123 families. These figures are merely indicative, and their use here is to fill a lamentable informational void due to the collective failure of the mainland government and its international collaborators, as a result of an appreciation deficit of the pastoral fauna as the foundational livelihood activity in Soqotra as well as a key enabler of the island's biodiversity preservation.

\section{Conclusion: from incremental adaptation to transformational accommodation}

Given the constantly evolving transition process in Soqotra, there cannot be any ultimate 'conclusion' to this discussion, instead only a provisional assessment can be offered about the nature of changes within the Soqotran community thus far. Indeed, Soqotran pastoralists have been engaged in a series of internal adjustments vis-à-vis the externally imposed imperatives that are reconfiguring their communal repertoire of livelihood practices. The socio-cultural transformation of the pastoralists is due to the cumulative effects of the political mobilization strategies and the economic policies of the mainland government since 1967. The result is a series of spatial displacements and social mutations, which are summarized below in terms of the changes in the Soqotran pastoralists' domains of livelihood, residential location and socio-cultural milieu:

The impact of the spatial displacement that took place within Soqotrans' domains of livelihood - that is, the spatial/territorial domains, and the resources contained therein, from which Soqotrans eke out a living - is best characterized as the delinking of livelihood making from its traditional locales. The initial symbiosis between the pastoralist and his grazing grounds, as manifested in the seasonal circularity of the transhumant pattern of merqiyo and mezhiro, has partially unraveled under the pressure of the island's external entanglements. The end result is a transition, still unraveling, from an environmental dependency linked to the pursuit of human survival through a pastoral mode of subsistence to a cash dependency on non-pastoral activities that are tenuously linked to the cultural continuity of a marginalizing pastoral way of life.

The residential location of Soqotrans has been the most susceptible to external entanglements. The change in residential location was part of an initial process of socializing troglodytic pastoralists, and subsequently of spatial demarcation of the island to accommodate the changing political geography of the different regimes introduced from the mainland. More significantly, the expansion of road construction and public sector postcreation accelerated the shift in the island's population distribution from the hinterland to the coast.

The shift in socio-cultural milieu occasioned by the island's external entanglements is perhaps most significant, since it represents the culmination of a series of state-engendered delocalization initiatives. Indeed, this shift does not merely exemplify a topographical displacement from mountains to coast or from rural to urban, but from one cultural universe to another: from bādiya (hinterland) to madina (city). One of the many consequences of this shift is the conversion of the herdsmen into townsmen, as the former seek to accommodate Soqotra's newly imported way of life. The main reason is to ensure the future of the new generation, which entails attending school to learn how to read and write Arabic and English with the ultimate goal of getting a salaried position. For the new generation, the ideal of success is a job with a regular salary that alienates them from their pastoralist upbringing, which has already brought about a profound mutation in Soqotra's pastoral way of life.

In effect, the above discussion of socio-cultural changes in Soqotran pastoralists' lifestyle represents a series of internally driven incremental adaptations to a changing economic context. In contrast, there is another source of change that is being generated through an externally enforced transformational accommodation of pastoralists as well as non-pastoralist Soqotrans to an islandwide environmental management regime. The primary manifestation of this regime is the 'Zoning Plan for the Soqotra Archipelago: For the Conservation and Sustainable Use of Biodiversity and Natural Resources'. This Zoning Plan was formulated by international consultants and decreed into law by the Yemeni state in 2000. The implementation of this Zoning Plan is managerially accountable to, and financially dependent on, international agencies. It proposes a total encompassing of the island in which not a single square mile of the island is not under some kind of regulatory edict. The latter makes excessive use of the idiom of exclusion, protection and control: lots of sticks but no carrots. Consequently, the plan's virtual reconfiguration of the island's landscape betrays a pervasive disconnect between the demarcated zones and Soqotrans' normal 
pursuit of their traditional livelihoods. This is tantamount to the symbolic, if not de facto, expropriation of their pastoral land as over $75 \%$ of the island's surface is under the IUCN strict protection category (national park and nature reserve) in which humans are considered an invasive species! The subsequent inclusion of the island in UNESCO's World Heritage Sites in 2008 enhanced its global recognition. All of these measures have engendered a number of unintended consequences in the form of perverse outcomes, outlined below.

The rise in local expectations from international assistance was subsequently followed by the spread of disappointment with, and chronic doubts about, international donors' projects and promises. The disappointment was due to the implementation of an incongruous nature-preserving, pastoral livelihood-neglecting and modernizationprevention 'sustainable development' model for the island that far exceeds the exigencies of environmental conservation. The formulation of this proscriptive conservation regime was driven more by opportunistic space appropriation by the Zoning Plan designers due to the carte blanche given by the national government, rather than an ecological imperative based on a substantiated analysis of the threats to the island's environment. This, in turn, has led to the estrangement of most Soqotrans from international donors' environmental protection initiatives, since these initiatives were chronically unable to demonstrate that biodiversity conservation through the sustainable use of local environmental resources could produce economically viable livelihoods.

The promotion of a tourism economy has quickly degenerated from the ideal of an 'ecologically sensitive low-volume tourism' with pastoralists as its primary beneficiaries to the reality of an ecologically indifferent mass tourism that has benefitted mostly urban-based Soqotrans. Paradoxically, it was the promise of this tourism economy that led the government to construct a $430-\mathrm{km}$ network of asphalted roads that is now seen as a threat to the island's biodiversity. Relatedly, this tourism economy caused a coastal land grab by external actors and exacerbated local disputes over the communal ownership of land. These disputes were animated by local expectations that potential external interests in land as conservation enclaves or tourist business ventures would become a source of rent extraction. This created incentives to monetize communal land holdings through the privatization of property rights.

The spread of a car culture on the island has resulted from the investments of the Soqotran diaspora in the Arabian Gulf in response to income-generating opportunities in the emerging tourism economy. As of January 2014, according to the Director of Traffic Police, there were a total of 1,716 cars on the island, constituting a ratio of one car for every 29 inhabitants. Indeed, the car has become the key investment asset of individual participants in the tourism economy as the means of transport for 'ecotourists', environmental researchers and project managers, and thus further contributing to environmental stress. Also, the car has achieved the status of a consumer fetish that is breeding social competition and differentiation within the hinterland. There is now the frequent incongruous site of a relatively new car parked next to an archaic compound, thereby accelerating the demise of the hinterland's communal ethos of 'subsistence egalitarianism'.

In light of the above, conservation practitioners, both local and foreign, should temper their conservationist zeal and recalibrate the Zoning Plan, which has configured the entire island into a 'territorial set-aside' for the sake of the globe's environmental health, while threatening pastoralists with displacement from their livelihood domains. This recalibration process should entail the articulation of a locally adapted sustainable development vision for Soqotra: (a) that prioritizes the role of pastoralists and their herds based on empirically established knowledge about the livestock population, and about the current status of the practice of transhumance, (b) that formulates socioculturally informed proposals on the economic potentials of pastoralism, and (c) that indigenizes the values guiding the island's environmental protection regime.

\section{Endnotes}

${ }^{a}$ The herding of sheep seems to be the primary, if not exclusive, responsibility of women; however, males in the western part of the island herded sheep as well. More generally, men were in charge of adult livestock, while women were in charge of immature ones (personal communication with Dr. Miranda Morris).

${ }^{\mathrm{b}}$ In this regard, Soqotra seems to be an exception, given that 'A constant factor among pastoral populations is the assignation of milk and milking to women' (Blench 2000: 30). In Soqotra, this is true only in the case of sheep, as noted above.

${ }^{\mathrm{C}}$ In addition, as the number of sheep $(7,825)$ for Eastern district as reported in its development report seemed too low, I have added the figures for sheep $(18,455)$ collected by the 'Community-Based Livestock Development and Marketing Improvement Project', which got reliable figures in exchange for vaccination. However, the project intervened in only a few areas within the Eastern district.

${ }^{\mathrm{d}}$ The above estimation is based on the more frequently used figure of the island's landmass as measuring $3,625 \mathrm{~km}^{2}$. However, the Central Statistical Organization of the Government of Yemen gave the author the following dimensions for each district: East 2,701 $\mathrm{km}^{2}$, and West $1,002.5 \mathrm{~km}^{2}$ for a total of $3,703.5 \mathrm{~km}^{2}$ for the island. Also, there are two more figures of the size of Soqotra Island that are in use in the public domain: 3,650 and 3,796 $\mathrm{km}^{2}$. 


\section{Competing interests}

The author declares that he has no competing interests.

\section{Authors' information}

SDE has a D.Phil. in social anthropology from the University of Sussex, UK. He is a former international development professional at the United Nations Development Programme. He is currently a Research Associate at the Yemen Center for Studies and Research in Sanaa. He has published in over 20 academic journals. His research area is state-society relations in the Middle East/West Asia. He is completing a book manuscript on the historical process and contemporary ramifications of the Yemeni state's politics of incorporation of a sub-national communal formation.

\section{Acknowledgements}

The author acknowledges the useful suggestions of the anonymous reviewers of the Pastoralism journal and the appreciation and constructive feedback of the journal editor, Carol Kerven. Also, a special thanks to Dr. Miranda Morris for her critical reading of the manuscript and assistance with the Soqoți terms (although I have not always used the diacritical marks suggested). This article is an abbreviated version of a longer chapter in a book manuscript under preparation.

Received: 27 April 2014 Accepted: 8 September 2014

Published online: 08 October 2014

\section{References}

Blench, RM. 2000. You can't go home again. Extensive pastoral livestock systems: Issues and options for the future. www.oneworld.org/odi/rfs/r.blench.

Brown, GH. 1966. Social and economic conditions and possible development of Socotra. Aden: Federal Government Mission Report.

Central Statistical Organization (CSO). 2004. The final results of the general census for population, housing and establishments 2004. Sanaa: CSO.

Commission of the European Communities (EU). 2000a. Soqotra Archipelago Master Plan. Sana'a: MoPD.

Commission of the European Communities (EU). 2000b. Sectoral Report: Agriculture and Livestock. Sana'a: MoPD.

De Sanctis, M, A Adeeb, A Farcomeni, C Patriarca, A Saed, and F Attorre. 2013. Classification and distribution patterns of plant communities on Socotra Island, Yemen. Applied Vegetation Science 16(1): 148-165.

Elie, SD. 2004. Hadiboh: From peripheral village to emerging city. Chroniques Yémenites 12: 53-81.

Elie, SD. 2006. The waning of a pastoralist community: An ethnographic exploration of Soqotra as a transitional social formation. University of Sussex, UK: D.Phil. dissertation.

Elie, SD. 2009. State-community relations in Yemen: Soqotra's historical formation as a sub-national polity. History and Anthropology 20: 363-393.

Elie, SD. 2012a. Cultural accommodation to state incorporation in Yemen: Language replacement on Soqotra Island. Journal of Arabian Studies 2: $39-57$.

Elie, SD. 2012b. Fieldwork in Soqotra: The formation of a practitioner's sensibility. Practicing Anthropology 34: 30-34.

Elie, SD. 2014. Soqotra's pastoral economy: From core to auxiliary livelihood. Pastoralism: Research, Policy and Practice. in press.

Ellen, R. 1982. Environment, subsistence and system: The ecology of small-scale social formations. Cambridge: Cambridge University Press.

Ellen, R. 1994. Modes of subsistence: Hunting and gathering to agriculture and pastoralism. In Companion encyclopedia of anthropology: Humanity, culture and social life, ed. T Ingold, 197-225. New York: Routledge.

Khazanov, AM. 1994. Nomads and the outside world, 2nd ed. Madison: University of Wisconsin Press.

Miller, A, and M Morris. 2004. Ethnoflora of the Soqotra Archipelago. Edinburgh: Edinburgh University Press.

Miller, AG, MJ Morris, and RA Atkinson. 2003. Conservation on Soqotra: Ravaging goats or climatic change, Proceedings of the Yemeni Scientific Research Foundation, Science Conference 2002, 173-182.

Morris, M. 2002. Soqotra Archipelago: Manual of traditional land-use practices. Edinburgh: Royal Botanic Garden.
Naumkin, V. 1993. Island of the Phoenix: An ethnographic study of the people of Socotra. Reading: Ithaca Press.

Swift, J, and C Toulmin. 1992. Guidelines and strategies for pastoral development in Africa, Paper prepared for the UNICEF/UNISO project on Nomadic Pastoralists in Africa (NOPA) and based on the report "Pastoralist at a Crossroads" published by NOPA in 1992.

doi:10.1186/s13570-014-0016-3

Cite this article as: Elie: Pastoralism in Soqotra: external entanglements and communal mutations. Pastoralism: Research, Policy and Practice 2014 4:16.

\section{Submit your manuscript to a SpringerOpen ${ }^{\odot}$ journal and benefit from:}

- Convenient online submission

- Rigorous peer review

- Immediate publication on acceptance

- Open access: articles freely available online

- High visibility within the field

- Retaining the copyright to your article

Submit your next manuscript at $>$ springeropen.com 